\title{
Mídia e maioridade penal: Programa Estação Direitos e a construção de um contradiscurso em defesa de crianças e adolescentes
}

\author{
Media and the age of criminal responsibility: \\ Program Estação Direitos and the elaboration \\ of a counter-discourse to defend children and \\ teeneagers
}

\author{
Lorena Cruz Esteves \\ Luciana Miranda Costa* \\ Danila Cal ${ }^{* * *}$
}

\begin{abstract}
Resumo: Ao tratar sobre ato infracional, a cobertura midiática tem sido tendencialmente negativa e comumente viola os direitos humanos dos adolescentes, garantidos pelo Estatuto da Criança e do Adolescente (ECA), influenciando o debate público acerca da redução da maioridade penal. Partindo desse contexto, o objetivo geral deste artigo foi identificar as características e estratégias discursivas presentes no programa de rádio Estação Direitos, produzido pela ONG Rádio Margarida, para compará-las ao discurso dominante veiculado pelos meios de comunicação hegemônicos, especialmente programas de rádio e televisão. A metodologia partiu de um estudo comparativo entre a análise do Estação Direitos e a literatura sobre o tema. $\mathrm{O}$ corpus da pesquisa é composto pelo recorte dos cinco programas que trataram sobre a temática, a partir da metodologia da Análise do Discurso. As
\end{abstract}

*Doutoranda do Programa de Pós-Graduação em Comunicação, Cultura e Amazônia na UFPA. Mestrado em Comunicação, Cultura e Amazônia (2014) pela UFPA. Graduada em Comunicação Social (2008) pela UNAMA. Servidora da Secretaria de Comunicação do Estado do Pará. E-mail: estevesjornalismo@gmail.com.

${ }^{*}$ Doutora em Desenvolvimento Sustentável do Tropico Úmido (2004) pela UFPA; Pós-doutora (2013) pela UNL ( Portugal) e 2020 pela UFRN. Mestrado em Desenvolvimento Sustentável do Trópico Úmido ( UFPA) Graduada em Comunicação Social pela PUC-SP. Professora do Departamento de Comunicação Social e do Programa de Pós-Graduação em Estudos da Mídia na UFRGN. E-mail: Imirandaeua@hotmail.com.

*** Doutora em Comunicação Social pela UFMG (2014), Pós doutora pela UFMG (2016). Mestrado em Comunicação Social pela UFMG (2007). Graduada em Comunicação Social pela UFPA (2004).Professora Faculdade de Comunicação e do Programa de Pós-Graduação Comunicação, Cultura e Amazônia (PPGCom), da Universidade Federal do Pará (UFPA). E-mail danilagentilcal23@gmail.com.

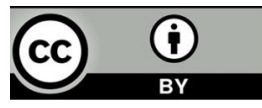

This content is licensed under a Creative Commons attribution-type BY 
conclusões indicam que o programa, ao tratar sobre maioridade penal, trouxe à luz outras perspectivas de enquadramento, indo ao encontro do ECA e construindo um contradiscurso em relação aos padrões de cobertura da mídia hegemônica.

Palavras-Chave: Mídia. Maioridade Penal. ECA.

\begin{abstract}
When dealing with an infraction, media coverage has been tending to be negative and commonly violates the human rights of adolescents, guaranteed by the Statute of Children and Adolescents (ECA), influencing the public debate about reducing the age of criminal responsibility. From this context, the general objective of this article was to identify the characteristics and discursive strategies present in the radio program Estação Direitos, produced by the NGO Rádio Margarida, to compare them to the dominant discourse conveyed by the hegemonic media, especially radio and television programs. The methodology was based on a comparative study between the analysis of Estação Direitos and the literature on the subject. The corpus of the research is composed of the clipping of the five programs that dealt with the theme, from the methodology of Discourse Analysis. The conclusions indicate that the program, when dealing with criminal legal age, brought to light other framing perspectives, meeting the ECA, and building a counter-discourse in relation to the coverage patterns of the hegemonic media.
\end{abstract}

Keywords: Media. Age of criminal responsibility. ECA.

Recebido em 23/07/2020. Aceito em 03/11/2021.

\title{
Introdução
}

A criminalidade juvenil é um tema frequentemente debatido no Brasil. Quando adolescentes cometem atos infracionais violentos, o fato gera grande repercussão e opiniões polêmicas e divergentes. Nesse contexto, a preocupação em torno da redução da idade penal surge como uma política criminal que vem sendo difundida há décadas no país, considerada por $84 \%$ da população, segundo pesquisa do Datafolha $(2019)^{1}$, a melhor maneira de diminuir a violência praticada por adolescentes.

O discurso favorável à redução ganhou maior notoriedade ${ }^{2}$ no cenário político com a emergência de um governo de extrema direita eleito no Brasil (SAFATLE, 2019), dirigido pelo presidente da República Jair Bolsonaro, que tem defendido uma punição mais rigorosa para adolescentes envolvidos com a lei, sugerindo, inclusive, que o Estatuto da Criança e do Adolescente - ECA

\footnotetext{
${ }^{1}$ Contrários à mudança são 14\%; indiferentes ou não souberam responder somam 2\% (CERIONI, 2019).

${ }^{2}$ Ressaltamos que houve maior notoriedade do discurso favorável à redução da maioridade penal, em função da sua validação pela autoridade máxima do executivo do país, porém, em período anterior à eleição de Bolsonaro essa ideia já era bastante discutida, sendo inclusive objeto de propostas na Câmara dos Deputados.
} 
(BRASIL, 1990) fosse "jogado na latrina", porque, na sua opinião, estimula a "vagabundagem e a malandragem infantil” (SOARES, 2018). A ascensão de um governo de ultradireita coloca em xeque os direitos garantidos nos últimos trinta anos, desde a criação do ECA, em 1990.

De acordo com Ribeiro (2020), a grande mídia, de forma geral, vem contribuindo para a construção de um "retrato distorcido do adolescente em conflito com a lei" (p. 26), influenciando o debate público no sentido de uma clara defesa da redução da idade penal dos adolescentes. Os programas considerados policialescos, pautados por uma linha editorial sensacionalista, são os que durante a cobertura policial, comumente desrespeitam os direitos humanos e estimulam a punição como tônica dos discursos (ANDI, 2013; VARJÃO, 2015; ALVES, 2018; RIBEIRO, 2020).

O programa de rádio Estação Direitos, objeto deste artigo, foi produzido pela Organização Não Governamental Rádio Margarida, de Belém do Pará, a partir de 2010, uma instituição com 30 anos de atuação em defesa dos direitos de crianças e adolescentes na Amazônia paraense. Ele foi idealizado para divulgar e efetivar o Estatuto da Criança e do Adolescente, sendo direcionado à população em geral e aos profissionais que atuam na rede de defesa dos direitos de crianças e adolescentes, como professores, conselheiros tutelares e assistentes sociais. Para isso, foram produzidos programas semanais de radiodifusão em uma emissora FM e conteúdos e materiais educativos em áudio, vídeo e impressos, difundidos no portal web (www.radiomargarida.org.br).

Pioneiro no estado do Pará, com formato e propostas específicos, o Estação Direitos foi primeiramente veiculado na Rede Cultura de Rádio (Cultura FM e Cultura Ondas Tropicais) ${ }^{3}$ e, posteriormente, na Rádio Unama FMํ, entre 2010 e 2012. O programa foi ao ar semanalmente, com uma hora de duração, todos os sábados, das $9 \mathrm{~h}$ às $10 \mathrm{~h}$ da manhã. Ao longo de dois anos e quatro meses, foram produzidos 104 esquetes inéditos, com temáticas diversas, referentes a datas comemorativas do calendário da infância ou ainda baseadas em assuntos factuais que estavam em discussão na mídia.

Durante uma hora, o programa apresentava diversos formatos, como quadros, reportagens, enquetes, spots e radionovelas. Mas, a maior parte da programação era composta por entrevistas, ao vivo, com especialistas na temática da infância e adolescência, como pedagogos, conselheiros tutelares, advogados, defensores públicos, psicólogos e assistentes sociais. Também faziam parte da conversa representantes do governo, que tinham naquele espaço uma oportunidade de expor o que o Estado estava fazendo sobre aquela determinada área, além de ouvintes que ligavam para participar ao vivo.

Vale ressaltar ainda, que o programa foi produzido por uma equipe interdisciplinar formada por comunicólogos e assistentes sociais, com apoio de um comitê formado por diversas instituições e profissionais, que trabalhavam, à época, na rede de enfrentamento à violação de direitos de crianças e adolescentes. A proposta de utilização das ondas sonoras se deu em função da maior facilidade na linguagem, baixo custo, possibilidade de alcançar um público vasto e diversificado, principalmente no interior da Amazônia; e ainda por ter sido veiculado em emissoras que não apresentam caráter comercial, e, sim, educativo-cultural, portanto, mais acessíveis e receptivas a um formato cujo principal gênero não era o entretenimento.

Partindo desse contexto, analisamos os discursos veiculados pelo Estação Direitos sobre a redução da maioridade penal em comparação ao produzido pelos meios de comunicação

\footnotetext{
${ }^{3}$ As rádios Cultura FM e OT integram a Fundação Paraense de Radiodifusão (Funtelpa), uma instituição pública de direito privado, mantida prioritariamente com recursos do Governo do Estado do Pará.

${ }^{4}$ A Rádio Unama FM (105,5 Mhz) é uma emissora educativa, instituída pela Universidade da Amazônia, uma instituição de educação superior privada.
} 
hegemônicos, tomando como base a análise do programa de rádio e a literatura sobre o tema. Com esse objetivo, organizamos este artigo em três seções: na primeira, apresentamos os avanços da legislação brasileira referente aos direitos e responsabilização dos adolescentes, por meio da criação do Estatuto da Criança e do Adolescente; na segunda, tratamos sobre a cobertura midiática relacionada a atos infracionais que comumente viola os direitos dos adolescentes e contribui para a reprodução de um pensamento cristalizado a respeito da maioridade penal; por último, a metodologia que orienta esta pesquisa, seguida da análise dos dados.

\section{Estatuto da Criança e do Adolescente e a Maioridade Penal}

O Estatuto da Criança e do Adolescente é a Lei federal 8.069, de 13 de julho de 1990, que substitui o antigo Código de Menores, atendendo ao disposto no artigo 227 da Constituição Federal (BRASIL, 1988). O grande mérito do ECA foi a criação de normas para que se respeitem a criança e o adolescente como cidadãos sujeitos de direitos e deveres, conferindo-lhes prioridade, sobretudo na elaboração e implementação de políticas públicas (PASTORELLI, 2001; ROTHBERG, 2011; ALVES, 2018). São sujeitos deste dispositivo legal, crianças de até 12 anos incompletos e adolescentes com idades entre 12 e 18 anos incompletos. Todos e todas sujeitos com direitos e deveres, que devem ser assegurados acima de tudo e sem distinção de cor, religião ou situação econômica e com prioridade absoluta dentro das políticas públicas.

De acordo com a Constituição Federal, cabe à família, ao Estado e à sociedade zelar pelas crianças e adolescentes, colocando-os "a salvo de toda forma de negligência, discriminação, exploração, violência, crueldade e opressão”. (BRASIL, 1988, art. 227). Em função de estarem em processo peculiar de formação, não respondem por seus atos como adultos e, por isso, não podem ser encaminhados ao sistema prisional, o que não quer dizer, no caso específico dos adolescentes, que não sejam responsabilizados quando há conflito com a lei. Existem interpretações discordantes por parte da sociedade em geral que não reconhece a diferença entre maioridade penal e imputabilidade penal. O ECA considera os adolescentes inimputáveis (BRASIL, 1990, art 6º).

A maioridade penal é a idade mínima a partir da qual uma pessoa é "reconhecida como adulto consciente das consequências de suas atitudes, sendo capaz de responder de forma integral por suas ações nas esferas civil e criminal" (RODRIGUES, 2018, p. 21). Por sua vez, a "responsabilidade penal", no Brasil, começa aos 12 anos, e a "imputabilidade penal" é a maioridade penal, na qual a pessoa responde como adulto por seus atos (ODON, 2013).

A imputabilidade penal é, segundo Amaro (2004) e Alves (2018), o conjunto de condições pessoais que garantem que o sujeito é "mentalmente são e desenvolvido", capaz de compreender a dimensão de uma ação de caráter ilícito e de conformar seus atos de acordo com esse entendimento. A imputabilidade pode ser excluída por determinadas causas, denominadas causas de inimputabilidade. A menoridade penal também constitui uma das causas de exclusão da imputabilidade, abrangida pela expressão "pessoas em desenvolvimento", disposta no ECA (BRASIL, 1990, art. 6º).

A conduta ilegal realizada por adolescentes possui responsabilização diferenciada em relação a adultos. Aos adultos, o objetivo é punir; aos adolescentes, o objetivo é reeducar, por isso, são encaminhados a cumprir medidas socioeducativas, quais sejam: I - advertência; II - obrigação de reparar o dano; III - prestação de serviços à comunidade; IV - liberdade assistida; V - inserção em regime de semiliberdade; e VI - internação em estabelecimento educacional (ECA, 1990, art. 112). O processo de socioeducação é regulamentado pela Lei 12.594/2012 que institui o Sistema 
Nacional de Atendimento Socioeducativo - Sinase. Por meio da execução das medidas, o objetivo é fortalecer os vínculos familiares e comunitários, "estimulando a autonomia, a melhoria das relações interpessoais e o fortalecimento de redes de apoio aos adolescentes e suas famílias" (SINASE, 2012, art. 60).

Essas diretrizes têm ocasionado questionamentos por parte da sociedade que considera que adolescentes autores de atos infracionais não são responsabilizados por seus atos (ALVES, 2018; RODRIGUES, 2018). Desde que o Estatuto entrou em vigor, diversas propostas de emendas constitucionais procuram revisar essa condição. Em 2015, a Câmara dos Deputados aprovou em segundo turno, a Proposta de Emenda à Constituição (PEC) no 171/93, de autoria do então deputado Eduardo Cunha, que reduz a maioridade penal de 18 para 16 anos no caso de crimes de homicídio doloso, lesão corporal seguida de morte e crimes hediondos, como o estupro. A matéria aguarda apreciação pelo Senado Federal.

Outras três Propostas de Emenda à Constituição, que tratam sobre a redução da maioridade penal, seguiam paralelamente em análise pela Comissão de Constituição, Justiça e Cidadania (CCJ) do Senado Federal: 74/2011, 33/2012 e 21/2013, mas foram arquivadas. Há uma que segue em tramitação na CCJ, a 115/2015, juntamente a outra sobre o tema, apresentada em março de 2020, pelo senador Flávio Bolsonaro (Patriota), com apoio de outros 32 parlamentares. O texto da PEC 115/2015 estabelece que:

São penalmente inimputáveis os menores de dezoito anos, sujeitos às normas da legislação especial, ressalvados os maiores de dezesseis anos, observando-se o cumprimento da pena em estabelecimento separado dos maiores de dezoito anos e dos menores inimputáveis, em casos de crimes hediondos, homicídio doloso e lesão corporal seguida de morte (BRASÍLIA, 2020).

Entender os motivos para o fenômeno crescente do movimento a favor da redução da maioridade penal é um desafio posto, haja vista que não há apenas um fator que dê conta de explicá-lo. Outro fenômeno igualmente complexo é a marginalização que envolve crianças e adolescentes, vítimas e autores de violência. Sabe-se, no entanto, que a junção de múltiplos fatores que resumem uma conjuntura social, política, econômica e cultural tem parcela significativa no desenvolvimento de uma sociedade, mais especificamente, no comportamento de sua juventude.

O delito do adolescente revela múltiplas determinações: a distribuição desigual de rendas e de direitos de cidadania; a ausência de uma política para a juventude; a precariedade das políticas assistenciais para a criança e o adolescente em risco pessoal; a comunidade de convivência, que não se responsabiliza pelas suas crianças e jovens; a escola expulsiva; os meios de comunicação, que banalizam a violência; a família, que, inscrita na mesma base material e cultural da sociedade, não é um lugar de cuidados e fracassa no controle da conduta dos filhos (ANDRADE, 2006, p. 211, grifo nosso).

O debate público em torno de temas como a maioridade penal é marcado por momentos de grande visibilidade e silenciamento, porém, toda vez que um caso envolvendo adolescente autor de ato infracional ganha repercussão midiática, o tema volta a ser destaque na cena pública (CAL; SANTOS, 2015; ALVES, 2018; RODRIGUES, 2018), influenciando outros campos, como o jurídico e o político, por exemplo.

Considerando que a forma como a sociedade conceitua a infância e como percebe a juventude, influencia diretamente nos padrões de comportamento, nas leis de proteção e nas políticas 
públicas que porventura possam vir a beneficiar esse segmento da população (ALVES, 2018), a mídia passa a ter um papel fundamental, pois é capaz de definir mediações sociais, ou seja, regular a relação do indivíduo com o mundo e com seus pares (PAIVA; BARBALHO, 2005; ALVES, 2018).

\section{Mídia e a cobertura sobre atos infracionais}

Na contemporaneidade, a mídia tornou-se um dos "principais dispositivos" (GREGOLIN, 2008; MATTOS et al, 2012; ALVES, 2018) mediadores de sentidos (re) produzidos em sociedade, além das outras instituições tradicionalmente reconhecidas, como família, escola e comunidade. Portanto, por meio da mídia, os diversos discursos circulantes em uma determinada cultura são mantidos, reproduzidos ou reconstruídos, dependendo das relações de forças existentes.

Dessa forma, a mídia pode tanto utilizar seu potencial de dar visibilidade a determinadas concepções de mundo, contribuindo para o agendamento e monitoramento de temas prioritários para o debate público, pautando assuntos de interesse coletivo, como adotar um modelo dominantemente mercadológico, baseado na espetacularização dos fatos e no sensacionalismo em busca de maiores índices de audiência.

Quando o tema da cobertura midiática se refere à maioridade penal, há um acirramento do debate público com relação à forma como os adolescentes em conflito com a lei são vistos pela população, influenciando, inclusive, "o conjunto de leis que busca orientar o tratamento dispensado a esses garotos e garotas" (ANDI, 2012a, p. 8; ALVES, 2018). Os casos de grande repercussão nacional acarretam "um clamor da sociedade" por políticas públicas mais severas a adolescentes que cometem atos infracionais contra a vida, apresentando a redução da maioridade penal como solução para o "problema da lei e da ordem" (RODRIGUES, 2018, p.24).

Muitas publicações brasileiras apontam o tratamento fragmentado, superficial e descontextualizado da mídia quando trata sobre adolescentes que cometeram atos infracionais, infringindo os direitos humanos garantidos pelo ECA (CARLSON; VON FEILITZEN, 2002; BALAS..., 2000; NJAINE; VIVARTA, 2005; ANDRADE, 2006; NERY, 2008; ANDI, 2005, 2011, 2012a, 2012b, 2013; INTERVOZES, 2014; ROTHBERG, 2014; VARJÃO, 2015; ALVES, 2018).

Além disso, a cobertura sobre questões referentes aos adolescentes em conflito com a lei está relegada a um nível preocupante de invisibilidade (ANDI, 2012b, p. 63), uma vez que o assunto só ganha espaço nos meios de comunicação de massa quando associado a crimes graves contra a pessoa. Entre as principais tendências observadas nas coberturas realizadas pela mídia sobre adolescentes autores de atos infracionais, estão:

1. Centrado em crimes graves contra a pessoa envolvendo adolescentes.

2. Restrito à legislação que regula as regras de responsabilização deste grupamento.

3. Focado na (pretensa) impunidade que seria garantida pelo ECA.

4. Reduz problemática à ação do sujeito, ignorando o contexto de produção do fenômeno.

5. Focado no ato infracional, negligenciando desdobramentos legais.

6. Limitado à defesa de mudanças na legislação que regula as regras de responsabilização.

7. Defende principalmente a redução da idade penal como solução para o fenômeno. (ANDI, 2013, p. 21-22). 
Esse tipo de cobertura acaba gerando inúmeros sentidos sobre a percepção que a sociedade brasileira tem com relação aos adolescentes em conflito com a lei, como o da percepção que os adolescentes são os grandes responsáveis pela violência que assola o país; que os adolescentes estão cada vez mais perigosos; que os adolescentes não são responsabilizados, podendo praticar crimes à vontade; que a solução para esse fenômeno crescente seria a repressão ao sujeito e o endurecimento da legislação; e que somente com a redução da maioridade penal e o encarceramento dos adolescentes é que haveria uma diminuição da violência (ANDI, 2013).

Partindo desse contexto e como já mencionado, este artigo irá analisar as características e estratégias discursivas do programa de rádio Estação Direitos para se contrapor ao discurso midiático dominante sobre a redução da maioridade penal produzido pelos meios de comunicação hegemônicos. Isso será feito a partir de um estudo comparativo, que tem como base a análise do programa Estação Direitos e a literatura sobre o tema.

\section{Metodologia}

Tomamos como referencial metodológico a Análise do Discurso (AD) de vertente francesa, especialmente no conceito de formações discursivas, como instrumental metodológico principal. o discurso é entendido aqui nos termos de Foucault, que o considera como uma família de enunciados que pertencem a uma mesma formação discursiva. Esta última pode ser definida como um conjunto de regras postas, instituídas historicamente, sempre determinadas no tempo e no espaço, "que definiram em uma dada época e para uma determinada área social econômica, geográfica ou linguística, as condições de exercício da função enunciativa” (FOUCAULT, 1995, p.136).

Para o autor, a análise de uma formação discursiva consiste na descrição dos enunciados que a compõem, por meio da identificação das regras de formação daquele discurso. Tais regras possibilitam determinar quais são os elementos que compõem o discurso, ou seja, identificar os conceitos, os enunciados, os objetos e as estratégias. Foucault considera que o sujeito não é dono de seu discurso e que pode assumir várias posições (dispersas) no decorrer de um enunciado. Essa dispersão refere-se a um sistema de relações que são estabelecidas ao longo da prática discursiva que revelam um conjunto anterior e adjacente de enunciados.

O contexto é um fator essencial para os analistas do discurso. De acordo com Maingueneau (1987 apud BRANDÃO, 2012, p.17), ao realizar a AD é necessário considerar: as instituições em que o discurso é produzido, pois elas delimitam fortemente a enunciação; os embates históricos, sociais que se cristalizam no discurso; e o espaço próprio que cada discurso configura para si, mesmo estando dentro de um interdiscurso ${ }^{5}$. Para Brandão (2012), o grande desafio da AD é não reduzir o discurso aos aspectos puramente linguísticos ou restringir a análise aos aspectos históricos sobre ideologia. A pesquisa deve levar em consideração que um discurso não é um fato isolado e que dele fazem parte diversas condições de produção (ARAÚJO, 2000 apud COSTA, 2013, p.22).

Tomando como base a metodologia adotada, identificamos os discursos produzidos pelo programa de rádio Estação Direitos sobre maioridade penal, para, em seguida, analisar se (e como) eles foram de / ao encontro da produção dominante na mídia brasileira. O corpus da pesquisa foi delimitado a partir de um recorte temático: a maioridade penal. Para isso, foram selecionados, dentro do universo total de 104 programas, todos os que trataram diretamente sobre a temática

\footnotetext{
${ }^{5}$ Possenti (2003) afirma que, de acordo com Charaudeau e Maingueneau (2002), "interdiscurso" é, em sentido restritivo, o conjunto de discursos do mesmo campo que mantêm relações de delimitação recíproca uns com os outros e, em sentido amplo, conjunto das unidades discursivas com as quais um discurso entra em relação explícita ou implícita.
} 
e também sobre questões relacionadas. Ao todo, foram selecionados cinco programas, conforme abaixo, com data de veiculação e título:

13/11/2010 - Ato infracional

20/11/2010 - Maioridade penal

16/04/2011 - Redução da idade penal

21/05/2011 - Ato infracional e medida socioeducativa

26/11/2011 - Campanha contra a redução da maioridade penal

Após transcrever o áudio dos programas, foram identificados os assuntos presentes em todos os discursos encontrados. Os assuntos mais recorrentes foram separados em grupos que refletiram as temáticas mais abordadas nos programas. Os grupos temáticos foram novamente agrupados em formações discursivas mais recorrentes, a saber: Política, com 142 discursos aproximadamente (56\%), e Jurídica, com 84 discursos, aproximadamente (36\%), totalizando 226 unidades discursivas (92\%).

Portanto, os discursos que compuseram os cinco programas radiofônicos analisados foram construídos a partir de formações discursivas, nas quais podem ser encontrados os sentidos das palavras e expressões presentes nos programas radiofônicos. Nesses discursos, foram destacadas 22 temáticas, listadas na tabela abaixo.

Tabela 1 - Temáticas mais abordadas nos programas radiofônicos

\begin{tabular}{l|c}
\hline \multicolumn{1}{c|}{ Temáticas } & No aproximado de discursos \\
\hline 1. Sistema Socioeducativo & 57 \\
\hline 2. Políticas Públicas & 41 \\
\hline 3. Responsabilização Penal & 17 \\
\hline 4. ECA & 16 \\
\hline 5. Contexto de violação de direitos & 14 \\
\hline 6. Linguagem Jurídica & 14 \\
\hline 7. Adolescentes como cidadãos de direitos & 11 \\
\hline 8. Dados estatísticos & 11 \\
\hline 9. Sistema Carcerário falido & 8 \\
\hline 10. Desconhecimento da população & 7 \\
\hline 11. Vingança & 6 \\
\hline 12. Criminalização dos adolescentes & 6 \\
\hline 13. Mídia & 6 \\
\hline 14. Condição Peculiar de Desenvolvimento & 6 \\
\hline 15. Tempo de Internação & 5 \\
\hline 16. Redução como Medida Simplista & 5 \\
\hline 17. Afeto & Total \\
\hline 18. Casos Reais & 5 \\
\hline 19. Extermínio da Juventude & 5 \\
\hline 20. Mudança na Lei & 3 \\
\hline 21. Cultura da Violência & 3 \\
\hline 22. Tendência à criminalidade & 250 \\
\hline
\end{tabular}

Fonte: Dados da pesquisa. 
Os dados acima destacados, referem-se ao conteúdo dos roteiros e das reportagens dos programas, bem como às enunciações dos entrevistados, dos ouvintes e das enquetes gravadas. Portanto, são esses discursos que iremos analisar a seguir. Os outros formatos utilizados nos programas, como spots, radionovelas, agenda cultural e quadros não foram considerados para esta análise, pois, não havia regularidade nos temas, ou seja, a maioria não tratava sobre maioridade penal, versava sobre direitos humanos de crianças e adolescentes de uma forma geral, não especificamente sobre o tema que serviu de recorte para esta análise.

\section{A construção do discurso do programa Estação Direitos sobre maioridade penal}

O "Universo Discursivo", ou seja, o conjunto de formações discursivas (MAINGUENEAU, 1984, p. 27) que trata sobre o tema da maioridade penal é amplo. Por isso, torna-se demasiadamente restritivo delimitar os discursos relacionados ao assunto em apenas um campo discursivo, como o jurídico, por exemplo. Há muito que esse assunto permeia diversos outros campos, como o político, o científico, o midiático e o econômico.

Ao analisar o corpus da pesquisa, pode-se delimitar um campo discursivo ${ }^{6}$ vasto, permeado por várias formações discursivas, com destaque para a Política e para a Jurídica que integram majoritariamente o universo discursivo tratado nos programas como um todo (cerca de $92 \%$ do total de discursos). Encontramos, em menor escala, outras formações, como a científica, a de base cristã e a midiática, que não serão analisadas neste artigo (cerca de $8 \%$ dos discursos).

Procurou-se, inicialmente, não fazer um recorte cujos espaços discursivos eram baseados na dicotomia contra ou a favor da maioridade penal. Cada formação discursiva aqui estudada possui um tema principal que aparece também em vários discursos, o que não exclui o fato de que nesses discursos não estejam inseridos outros temas, apenas há um que se sobressai ante aos outros. E, em algumas formações discursivas, como a política, por exemplo, nota-se discursos favoráveis e contrários à redução da maioridade penal, que tratam do mesmo tema, ou seja, os discursos possuem oposição semântica (FIORIN, 1995) ao tratar assuntos iguais.

\section{Os sentidos dos discursos e as formações discursivas}

\section{O Discurso Político}

Partindo dos discursos veiculados pelo programa Estação Direitos da ONG Rádio Margarida, explicitaremos os sentidos produzidos em comparação com o discurso midiático sobre o tema presente na literatura. As maiores críticas à abordagem da mídia são referentes às coberturas jornalísticas superficiais e fragmentadas, descontextualizadas em relação às políticas públicas da área e seu específico entendimento de causas possíveis e soluções cabíveis (ROTHBERG, 2014; ANDI, 2005, 2011, 2012a, 2012b, 2013; VARJÃO, 2015; ALVES, 2018).

A formação discursiva cujos discursos analisados são mais recorrentes é a que está relacionada à área Política, com enfoque para a temática das políticas públicas e para a responsabilidade

\footnotetext{
6 "Campo discursivo é um conjunto de formações discursivas que se encontram em concorrência, delimitam-se reciprocamente em uma região determinada do universo discursivo. 'Concorrência' deve ser entendida da maneira mais ampla; inclui tanto o confronto aberto quanto a aliança, a neutralidade aparente” (MAINGUENEAU, 1984, p. 36).
} 
do Estado na solução do problema (presente em 41 discursos - 29\%), considerando que ele é também o principal agente indutor e mantenedor do sistema de educação do país, além de ser o responsável pela Segurança Pública. Algumas palavras e expressões são recorrentes nos discursos analisados, como: governo, poder público, políticas públicas, Estado, conjuntura política, autoridades, agentes do Estado, criminalidade, violência, assassinatos e políticas sociais.

Observou-se que a maioria dos discursos encontrados trata do tema de forma genérica, destacando que é preciso investir em mais políticas públicas. "Não adianta reduzir a maioridade penal, se não melhorarem as políticas públicas do nosso país" (OUVINTE, VERENA LIMA, PROGRAMA 3, BLOCO 2)7 . Essa opinião é recorrente em todos os discursos, uns abordam de forma geral a questão, como o caso da ouvinte Verena, outros, tratam o assunto enfatizando a ausência de políticas públicas.

Você tem aí um número significativo de residências superlotadas, o que acaba cerceando uma série de direitos, você tem bairros decadentes, sem a mínima infraestrutura de lazer, de convivência social... você tem escolas precarizadas, você tem falta de atendimento no Sistema Básico de Saúde, então, poxa, num contexto como esse, o que que há de se esperar? (REPRESENTANTE DA ASSOCIAÇÃO PARAENSE DE APOIO ÀS COMUNIDADES CARENTES - APACC, DAVID VIEIRA, PROGRAMA 5, BLOCO 3).

Este é um dos discursos mais recorrentes quando se argumenta contra a redução da maioridade penal, pois a ineficiência de políticas públicas gera um contexto de violação de direitos (total de 14 discursos: 6\%), o qual, certamente, é uma das principais causas para o aumento da violência juvenil. Os discursos que tratam sobre o contexto de violação afirmam que antes de os adolescentes infringirem a lei, tiveram direitos cerceados, portanto, seriam fruto de uma conjuntura social. "Eu acredito que uma criança, um adolescente, ele não nasce e não cresce pensando que ele vai ser um criminoso e que vai entrar no mundo do crime, sempre há um contexto social que o empurra pra isso" (APRESENTADOR, PROGRAMA 4, BLOCO 3).

Este argumento relaciona-se diretamente ao das políticas públicas, haja vista o fato de que um ocorre (contexto de violação) em função da carência ou inadequação do outro (políticas públicas). O conceito de políticas públicas é entendido, na maioria das vezes, como uma responsabilidade do Estado. "O Estado é o principal responsável pela garantia de tal acesso, no entanto, acaba se tornando o principal violador de direitos, quando o mesmo não garante as políticas sociais" (OUVINTE, NEI PINHEIRO, PROGRAMA 5, BLOCO 3). Por este recorte, observa-se que o Estado também é responsabilizado pela não garantia dos direitos de crianças e adolescentes, ao passo que, em alguns discursos, principalmente, o de especialistas, a responsabilidade é dividida por todos, inclusive com a sociedade. "Não estou eximindo aqui o poder público de sua responsabilidade. Nós vivemos em um estado democrático de direito em que o poder público sim tem a sua responsabilidade, mas todos nós somos responsáveis" (PROMOTORA DA VARA DA INFÂNCIA E JUVENTUDE, IONÁ NUNES, PROGRAMA 2, BLOCO 2).

Em alguns casos, ocorridos principalmente na fala dos ouvintes, houve discursos que imputaram somente ao adolescente a responsabilidade pela violência cometida. "A redução da maioridade penal deve acontecer, pois, os jovens decidem o futuro, votando, né? No caso, também podem assumir seus atos (OUVINTE, BRUNO ROCHA, PROGRAMA 5, BLOCO 2). Esse discurso,

\footnotetext{
${ }^{7}$ As citações relacionadas às fontes do programa, para um melhor entendimento do leitor, estão referenciadas, conforme modelo: função/profissão/forma de participação + instituição (quando necessário) + o programa + o bloco.
} 
que representa o senso comum, na maioria das vezes, combatido por importantes instituições e organizações ${ }^{8}$ que se posicionam contra a redução da maioridade (RODRIGUES, 2018), também foi criticado por entrevistados do programa de rádio. "A culpa de todos esses problemas sociais tá sendo empurrada pros próprios jovens, os adolescentes, como se eles fossem os culpados por essa situação em que se encontra a sociedade" (VEREADOR DE BELÉM, MARCOS SILVA, PROGRAMA 3, BLOCO 2).

Ainda com respeito à responsabilização, a família foi citada em alguns discursos. Neste recorte, a ouvinte diz que os pais deveriam dar mais limites aos filhos: "Hoje os pais tão dando muita liberdade pros filhos, deixam de repreender e deixam eles fazerem o que querem" (OUVINTE, KELI JAQUES, PROGRAMA 1, BLOCO 3). Já o excerto abaixo destaca que toda a família se encontra em contexto de vulnerabilidade social.

Tem uma questão que eu acho importante ressaltar com relação a família, que aí o ECA já diz que é obrigação da família, da comunidade geral e do Estado garantir os direitos, só que infelizmente, quando a gente consegue expandir essa mobilização, a gente passa a culpabilizar a família e não pensa que essa família também tá completamente desassistida, também, tá alijada de seus direitos (MESTRE EM PSICOLOGIA SOCIAL, ALYNE ALVAREZ, PROGRAMA 3, BLOCO 4).

O discurso midiático, em geral, ao priorizar a perspectiva individual, ou seja, culpabilizar individualmente o adolescente, constrói a ideia de que a solução para a problemática se restringe à repressão ao sujeito, em detrimento de medidas preventivas e estruturais (ANDI, 2013). Nesse sentido, os trechos discursivos presentes nos programas analisados, em sua maioria, contemplaram diferentes posicionamentos, respeitando a doutrina da Proteção Integral, consolidada pelo ECA, que afirma que todos: família, Estado e sociedade são responsáveis pela garantia dos direitos e deveres de crianças e adolescentes do país (1990, art 4ª).

Entre as políticas públicas mais comentadas, esteve a Educação, apontada como a principal solução para diminuir a violência cometida por adolescentes. "As medidas socioeducativas não são suficientemente eficazes. Não adianta colocar o adolescente um tempo na cadeia e deixar ele voltar pro mundo do crime, é necessário investir em educação" (OUVINTE, TIMÓTEO LOPES, PROGRAMA 4, BLOCO 4).

Era de se esperar que a educação fosse a política pública mais citada, haja vista que o segundo relatório produzido pela Associação Nacional dos Centros de Defesa da Criança e do Adolescente - $\operatorname{ANCED}^{9}(2015$, p. 5) ressalta que "a inserção de crianças e adolescentes nos sistemas de ensino, além de insuficiente, é precária. Há graves e reiteradas violações aos direitos humanos na educação" o documento destacou salas lotadas, com número de alunos superiores aos referenciais normativos, prédios inadequados, falta e rotatividade de professores (a maioria dos casos pela baixa remuneração), situações agravadas nas regiões mais pobres e periféricas. Além disso, ao tratar sobre diversidade na educação, enfatizou-se que a "escola ainda é centrada em um referencial eurocêntrico, branco, machista e heteronormativo” (2015, p. 5), fato que exclui

\footnotetext{
${ }^{8}$ Entre elas estão entidades nacionais como a Conferência Nacional dos Bispos do Brasil (CNBB), a Ordem dos Advogados do Brasil (OAB), o Ministério Público Federal (MPF), a Fundação da Associação Brasileira dos Fabricantes de Brinquedos (ABRINQ), bem como organizações internacionais, como o UNICEF, a ONU e seu comitê para a Educação, Ciência e a Cultura (UNESCO) (RODRIGUES, 2018).

${ }^{9}$ Resumo executivo do II Relatório Alternativo sobre a Convenção Internacional sobre os Direitos da Criança (CDC), apresentado ao Comitê de Direitos da Criança da ONU, em 2015.
} 
milhares de crianças e jovens, com destaque para situação dos meninos negros, o grupo social que apresenta os piores indicadores sociais na educação.

Outras políticas públicas foram citadas nos programas analisados, porém, com menor recorrência, como saúde, situação econômica, assistência social, lazer, justiça restaurativa e socioeducação. $\mathrm{O}$ fato de as políticas públicas estarem entre os discursos mais recorrentes é uma pista essencial para entender a abordagem diferenciada que o programa produziu sobre a maioridade penal. Destacar a importância das ações estatais, como foi o caso, indica que mais do que tratar os fatos pelos fatos, houve a tentativa de situar o ouvinte sobre uma questão mais ampla e que são necessárias medidas em diversos campos, como educação e saúde, profissionalização, comunidade e família, indo além do encarceramento.

O Estado foi representado em quatro dos cinco programas analisados, ou seja, a voz oficial institucional foi ouvida. Em diversos discursos, havia uma situação de denúncia com relação às ações públicas, como neste caso em que o discurso relatou as precárias condições das unidades de internação, a falta de estrutura e serviços básicos.

Infelizmente muitas situações que às vezes a gente já pensava terem sido superadas, lamentavelmente ainda prevalecem como é às vezes nas situações de torturas ocorrendo dentro desses espaços de cumprimento de medida socioeducativa, principalmente os espaços da medida de internação. As situações de insalubridade, de péssimas condições de higiene, que as pessoas ali estão dividindo muitas vezes o espaço com ratos, com esgotos a céu aberto, infelizmente a escolarização não é feita da maneira adequada, conforme a legislação prevê (ADVOGADO DO CENTRO DE DEFESA DA CRIANÇA E DO ADOLESCENTE, BRUNO MEDEIROS, PROGRAMA 2, BLOCO 2).

Nesses casos, havia o espaço do contra-argumento. As ações do governo foram evidenciadas também, como no exemplo abaixo.

Dentro do atendimento socioeducativo, na medida do possível, com todos os limites, o Estado pode garantir, nós temos hoje conseguido garantir experiências de esporte, a escola, por exemplo... dentro das unidades de internação hoje as escolas são instaladas junto com a Seduc, coisa que até 2007, isso não se dava. Nós temos hoje de 13 a 14 oficineiros que são arte-educadores (...). A gente tem experiência de educação profissional junto com a SEPER (...). Nós tivemos parceria junto com o São José Liberto na produção de gemas e joias (ASSISTENTE SOCIAL DA FUNDAÇÃO DA CRIANÇA E DO ADOLESCENTE DO PARÁ - FUNCAP, ANA CLAUDIA GUEDES, PROGRAMA 1, BLOCO 2)

A escolha dos entrevistados revelou uma preocupação em ouvir especialistas no assunto, que atuam em diversas esferas e representam tanto a área pública quanto a privada, diferentemente do encaminhamento que a maioria das matérias e programas factuais veiculados na grande mídia fazem (ANDI, 2012a; ALVES, 2018). Na maioria das vezes, apenas as vozes oficiais são ouvidas, como a da polícia, ou mesmo as informações são reproduzidas baseadas somente nos boletins de ocorrência das delegacias ou nos relatos de testemunhas, "embora o assunto envolva diretamente outras instâncias e instituições - tais como o Judiciário, o Ministério Público e as unidades de atendimento e seus profissionais -, é preponderante a participação da Polícia" (ANDI, 2012a, p. 18). 
Abaixo, apresentamos um quadro com a formação / ocupação dos especialistas convidados:

Quadro 1 - Ocupação/formação dos entrevistados dos programas

\begin{tabular}{|l|}
\hline \multicolumn{1}{|c|}{ Ocupação/Formação } \\
\hline Advogado do Centro de Defesa da Criança e do Adolescente - Cedeca Emaús \\
\hline Advogada do Centro de Defesa da Criança e do Adolescente - Cedeca-Emaús \\
\hline Assistente Social da Fundação da Criança E do Adolescente do Pará - Funcap \\
\hline Promotora da Infância e Juventude do Ministério Público do Estado \\
\hline Vereador de Belém \\
\hline Mestre em Psicologia Social \\
\hline Advogada e presidente da Comissão dos Direitos da Criança e do Adolescente - OAB-PA \\
\hline Mestre em psicologia e ex-diretor da Febem-SP \\
\hline Tenente da $1^{1}$ zona de policiamento da capital \\
\hline Jornalista do Unipop - Instituto Universidade Popular \\
\hline $\begin{array}{l}\text { Coordenador de Educação para a Cidadania da Apacc - Associação Paraense de Apoio às Comunidades } \\
\text { Carentes }\end{array}$ \\
\hline Presidente da Funcap - Fundação da Criança e do Adolescente do Pará \\
\hline Assistente Social do Centro de Referência e Assistência Social (CREAS) de Ananindeua \\
\hline
\end{tabular}

Fonte: Dados da Pesquisa

Nesse sentido, também houve um equilíbrio na escolha das instituições, civis e governamentais, corroborando o objetivo do programa de ouvir as duas esferas, convidando especialistas que tratassem sobre o assunto de forma mais conceitual e outros que informassem o que realmente estava sendo feito pelo Estado sobre o caso. Abaixo, um quadro com as instituições convidadas:

Quadro 2 - Instituições convidadas nos programas

\begin{tabular}{|l|l|}
\hline \multicolumn{1}{|c|}{ Civil } & \multicolumn{1}{c|}{ Governamental } \\
\hline $\begin{array}{l}\text { Centro de Defesa da Criança e do Adolescente - } \\
\text { Cedeca Emaús }\end{array}$ & $\begin{array}{l}\text { Fundação da Criança e do Adolescente do Pará } \\
\text { - Funcap }\end{array}$ \\
\hline Unipop - Instituto Universidade Popular & Promotoria da Infância e Juventude da Capital \\
\hline $\begin{array}{l}\text { Apacc - Associação Paraense de Apoio às } \\
\text { Comunidades Carentes }\end{array}$ & Câmara Municipal de Vereadores de Belém \\
\hline $\begin{array}{l}\text { Comissão dos Direitos da Criança e do Adolescente } \\
\text { - OAB-PA }\end{array}$ & Polícia Civil \\
\hline
\end{tabular}

Fonte: Dados da Pesquisa

Diversificar as fontes de informação é essencial para a compreensão de qualquer fenômeno (ROTHBERG, 2014). O noticiário em geral sobre as regras de responsabilização dos adolescentes em conflito com a lei apresenta insuficiência de vozes, é baseado em fontes oficiais, como a polícia, e resulta em enquadramento episódico, negligenciando a complexidade do fenômeno (ANDI, 2013; ROTHBERG, 2014; ALVES, 2018). Ouvir apenas uma fonte torna a informação superficial e fragmentada. Não é possível fazer uma boa matéria ouvindo apenas a polícia, por exemplo. 
Situação mais grave ocorre quando o discurso midiático desqualifica o campo de defesa dos direitos humanos - seus atores e dispositivos de ação, como os agentes que atuam no Sistema de Garantia dos Direitos (ANDI, 2015). Nessa perspectiva, é importante para garantir a pluralidade de opiniões, que fontes qualificadas sejam ouvidas, como o Ministério Público, a Defensoria Pública, Conselhos Tutelares e especialistas no assunto que possam oferecer as diversas visões sobre o assunto.

A temática referente ao sistema socioeducativo foi a segunda mais recorrente nesta formação discursiva relacionada à área Política, considerando, como já mencionado, que o Estado é o principal agente indutor e mantenedor do sistema de educação do país (presente em 33 discursos - 23\%), além de ser o responsável pela Segurança Pública.

Alguns discursos condenaram a aplicação do sistema socioeducativo:

Quando nós pensamos nas medidas socioeducativas, eu ainda vejo uma grande deficiência nelas, porque elas atuam em um único aspecto da vida dos adolescentes que é no ato que ele cometeu. Não existe um trabalho de reestruturação do ambiente sociocultural em que ele está inserido (MESTRE EM PSICOLOGIA, RICARDO SANTOS, PROGRAMA 4, BLOCO 1).

Outros discursos explicam o funcionamento do sistema socioeducativo. "Dentro das unidades, nós temos todo um projeto de atendimento socioeducativo, dividido por eixos: educação, saúde, profissionalização, direito ao esporte e ao lazer" (ASSISTENTE SOCIAL DO CENTRO DE REFERÊNCIA E ASSISTÊNCIA SOCIAL DE ANANINDEUA-PA, CARLA LAVAREDA, PROGRAMA 4, BLOCO 1).

$\mathrm{Na}$ esteira dessa perspectiva, também foi visibilizado o exemplo pontual do discurso de um adulto que na adolescência foi autor de ato infracional, cumpriu medida socioeducativa e conseguiu se ressocializar.

Meu cumprimento mesmo, lá socioeducativo, foi mais ter acompanhamento com o psicólogo, lá. Ela me incentivava. Ela foi me mostrando a realidade. Hoje em dia, graças a Deus, eu saí dessa vida e consigo pensar já no que eu posso fazer de bem (MELQUE SILVA VALE, 20 ANOS, AUTOR DE ATO INFRACIONAL QUE CUMPRIU MEDIDA SOCIOEDUCATIVA, PROGRAMA 4, BLOCO 1).

Com relação ao discurso referente ao sistema socioeducativo contemplado pela mídia dominante, as tendências registradas expõem um noticiário reducionista, que negligencia o sistema socioeducativo, seus desafios e potencialidades (ANDI, 2013). Em função disso, o assunto torna-se pouco conhecido pela população, gerando inúmeras dúvidas e questões controversas que ocorrem, principalmente, em função do desconhecimento da população sobre os conceitos que permeiam o universo da socioeducação, como o do SINASE (Sistema Nacional de Atendimento Socioeducativo) e de medidas socioeducativas. Quando citado na mídia, o foco do assunto é o ato infracional e a apreensão do adolescente. Em geral, a imprensa não aborda os desdobramentos legais e a imposição de medidas socioeducativas, enfatizando a reintegração do adolescente em conflito com a lei à sociedade (ANDI, 2013; ALVES, 2018).

A ênfase no ato infracional e o silenciamento a respeito dos processos de responsabilização, "alimentam a mentalidade de que os adolescentes podem praticar crimes à vontade, pois não são punidos, ou têm punição leve” (ANDI, 2013, p. 70). Este fato gera uma sensação de impunidade na população, fomentando discursos de vingança (presente em seis discursos nos programas 
analisados $)^{10}$. Os desdobramentos legais e o sistema de responsabilização são temas importantes para o entendimento de todo o processo que ocorre após a apreensão de um adolescente que cometeu ato infracional e precisam ter mais espaço na grande mídia.

Outras temáticas foram tratadas a partir dessa formação discursiva, porém, com pouca representatividade, como os discursos referentes à mortalidade da juventude (presente em 1\% do total analisado). "Os nossos adolescentes, eles não tão matando, eles tão morrendo, tão sendo vítimas” (MAX CORREA, INSTITUTO UNIVERSIDADE POPULAR, PROGRAMA 5, BLOCO 4). Esse assunto foi pouco tratado ao longo dos cinco programas, repetindo o mesmo tratamento dado pela mídia em geral que negligencia o aumento das causas externas (acidentes, suicídios, homicídios) de mortalidade de adolescentes. Pesquisa divulgada pelo Mapa da Violência (IPEA, 2019) constata que "no período de 1980 a 2017, as causas externas de mortalidade aumentaram drasticamente sua participação: os homicídios passaram de 19\% para 69\% no total de mortes de jovens de 15 a 29 anos de idade", sendo que o índice de homicídios de adolescentes negros é duas vezes maior que o dos adolescentes brancos.

O foco no cometimento de ato infracional grave também passa a falsa sensação de que esse compõe a maioria dos casos cometidos por adolescentes, quando os Levantamentos Nacionais do Sistema Socioeducativo demonstram que os atos cometidos mediante violência contra à pessoa representam menos de $10 \%$ do total de atos praticados. "A maioria dos atos infracionais não é contra a vida: $38,1 \%$ - roubo, 26,5\% - tráfico de entorpecentes (contra a incolumidade pública), $8,4 \%$ - homicídio e 5,6\% - furto (BRASIL, 2019). Não escamotear os casos nos quais os adolescentes cometem atos infracionais graves é não faltar com os fatos, já que não se pode dizer que os adolescentes não matam, roubam ou participam de infrações graves contra a lei, contra a vida e segurança de outros, porém, representam uma minoria diante do universo de atos infracionais praticados, além do fato de que há essa outra perspectiva da situação, com pouca abordagem na mídia, referente ao índice de homicídios contra adolescentes, principalmente quando se trata de adolescentes negros e pobres.

Vale destacar o fato de que alguns discursos presentes nos programas exemplificaram casos reais (presente em cinco discursos), nos quais os jovens são autores de violência, como: "Quem não se lembra do assassinato de um jovem casal de namorados em 2013 em uma casa do Rio de Janeiro e, mais recentemente, a morte do menino João Hélio, depois de um assalto ao carro em que passeava com a mãe?" (APRESENTADOR, PROGRAMA 2, BLOCO 1); e também discursos nos quais os adolescentes são vítimas da violência, como este:

Mesmo sabendo que não vai aliviar a dor e o sofrimento das famílias dos meninos cruelmente assassinados em Icoaraci, distrito de Belém, o Estação Direitos quer homenagear os irmãos Carlos Gabriel e Carlos Samuel Gonçalves; o primo deles Lenilson Mousinho; João Paulo Viana; Isaac Barbosa e Paulo Vitor Cunha (APRESENTADOR, PROGRAMA 5, BLOCO 1).

Quando a cobertura midiática silencia, por exemplo, o alto índice de mortalidade de adolescentes e hiperdimensiona os atos infracionais, centrando a abordagem nos crimes violentos, contribui para a construção de uma percepção social de que os adolescentes estão cada vez mais perigosos e são os grandes responsáveis pela violência praticada no país (ANDI, 2013; ALVES, 2018), como pudemos observar na fala deste ouvinte: “As autoridades não dá (sic) jeito

\footnotetext{
${ }^{10} \mathrm{O}$ discurso de vingança aparece no programa, não de forma direta, mas é citado pelos entrevistados, no sentido de afirmar que ele existe, mas, que não deve ser utilizado como justificativa para reduzir a maioridade penal.
} 
e a marginalidade tá tão grande que, se nós tirar tudo, vai ficar pouca gente no nosso mundo" (OUVINTE, PROGRAMA 1, BLOCO 3).

Essa percepção causa uma sensação de medo e insegurança, bem como, um comportamento reativo da população, que varia desde os discursos de vingança até a agressão física cometida contra os adolescentes em conflito com a lei, consequentemente, aumentando a sensação de uma cultura da violência (presente em dois discursos - 1\%). Esta temática também foi outro assunto pouco abordado no programa. O tema possui duas vertentes de interpretação: a cultura da repressão, da vingança, ou seja, a cultura de praticar violência contra aqueles que infringem a lei e o aumento da violência social como um todo que cria uma "sensação de insegurança constante".

Nós temos culturalmente a conduta da repressão, só que esta repressão na forma que ela está sendo proposta efetivamente, ela não é eficaz. Houve um crescente aumento de violência e não foi por causa das crianças e dos adolescentes, não foram eles que provocaram este aumento de violência. Por que que há este aumento crescente de violência? Pela total ausência de políticas públicas destinadas às famílias, então, infelizmente, a cultura da violência está instalada, mas reduzir a maioridade penal não vai resolver (PROMOTORA DA INFANCIA E DA JUVENTUDE DO MINISTÉRIO PÚBLICO DO ESTADO, IONÁ SILVA, PROGRAMA 2, BLOCO 1).

Essa percepção descontextualizada, problematizada nos programas radiofônicos analisados, contribui para formação de uma opinião pública a favor da redução da maioridade penal, sem levar em consideração que essa pode ser uma medida reducionista, baseada na resolução das consequências e não das causas da violência cometida por crianças e adolescentes, pois há uma conjuntura político-econômico-social e cultural a ser considerada.

\section{O Discurso Jurídico}

A segunda formação discursiva mais recorrente é a Jurídica. A temática principal abordada é referente também ao sistema socioeducativo (presente em 24 discursos), que foi a segunda mais recorrente na formação anterior, política. Neste caso, os discursos abordaram questões mais voltadas à legislação, como o conceito de SINASE: "O que é esse tal de SINASE? É um conjunto de diretrizes amplamente discutidas e criadas para orientar a conduta de todas as pessoas envolvidas no processo de socioeducação do adolescente em conflito com a lei" (REPÓRTER, PROGRAMA 5, BLOCO 2). Algumas palavras e expressões são recorrentes nos discursos analisados, como: legislação, leis, ECA, conflito, estatuto, advertência, pena, semiliberdade, medidas punitivas, liberdade assistida, direitos humanos, cidadão, Código, processo penal, decisão judicial.

Outras questões tratadas referem-se à aplicação das seis medidas socioeducativas.

As medidas socioeducativas são, por exemplo, advertência, prestação de serviços à comunidade, medida de internação, medida de semiliberdade. São essas medidas que o estatuto prevê ao adolescente, de doze até os dezoito anos. As medidas protetivas, elas são para as crianças, de até doze anos, que envolvem a própria advertência, o chamamento dos pais, a responsabilização dos pais, então elas envolvem outros assuntos (PRESIDENTE DA COMISSÃO DA CRIANÇA E DO ADOLESCENTE, DA ORDEM DOS ADVOGADOS DO BRASIL, SEÇÃO PARÁ, LUANA TOMAZ, PROGRAMA 1, BLOCO 1). 
O sistema socioeducativo, como já mencionado, é um assunto de pouco conhecimento da população. $O$ fato de estar entre os assuntos mais tratados nas duas formações discursivas mais recorrentes ao longo de todo o universo discursivo dos programas analisados é uma outra pista essencial para compreender que houve uma abordagem diferenciada do programa de rádio Estação Direitos, com relação à maioria dos discursos (re) produzidos na grande mídia. Outra pista é o fato de o ECA ser a segunda temática mais recorrente nesta formação discursiva (presente em 16 discursos). Os discursos que tratam sobre o Estatuto, em sua maioria, surgem no sentido de reafirmar o papel e a importância do ECA na garantia dos direitos humanos de crianças e adolescentes.

Exemplo 1: "A gente não pode dizer que o Estatuto não deu certo porque é cedo, nós só temos 20 anos de legislação." (PROMOTORA DA VARA DA INFÂNCIA EJUVENTUDE, IONÁ NUNES, PROGRAMA 2, BLOCO 3).

Exemplo 2: "Para quem não sabe, o ECA não existe só para proteger bandidos, como muitos acreditam, e sim para fazer valer os direitos e também os deveres de crianças e adolescentes" (APRESENTADOR, PROGRAMA 4, BLOCO 1).

Já alguns discursos especificam os direitos garantidos pelo ECA, citando indiretamente o Estatuto ou diretamente um ou mais artigos específicos.

Exemplo 1: "Entre os direitos de crianças e adolescentes defendidos pelo ECA, está o direito de meninos e meninas de conviver em família" (APRESENTADOR, PROGRAMA 5, BLOCO 3).

Exemplo 2: "O artigo 5 do ECA diz que toda a criança e adolescente tem direito a liberdade, ao respeito e a dignidade, como cidadãos civis, principalmente por estarem em processo de desenvolvimento humano" (APRESENTADOR, PROGRAMA 1, BLOCO 1).

O ECA é a principal legislação que orienta sobre os direitos e deveres de crianças e adolescentes no Brasil, no entanto, mesmo após mais de 30 anos de criação, o Estatuto enfrenta ainda diversos obstáculos para a sua consolidação, um deles é a questão que implica "a mudança do paradigma cultural, consolidado em um contexto histórico-social passado, que associava o suposto desvio da conduta do adolescente à exigência de enfrentamento correcional e punitivo" (ROTHBERG, 2014, p. 422). Portanto, 30 anos ainda é um tempo reduzido se considerarmos os mais de 100 anos de Códigos de Menores, que não percebiam a criança e o adolescente como Sujeitos de Direitos (presente em 11 discursos) ${ }^{11}$, merecendo tratamento diferenciado por estarem em uma situação peculiar de desenvolvimento.

A terceira temática mais abordada nesta formação discursiva refere-se à Linguagem Jurídica (presente em 14 discursos). Trata-se de uma questão importante, pois, os casos mais recorrentes de violação de direitos humanos na cobertura da grande mídia relacionam-se à forma como são tratados, sobretudo, os adolescentes em conflito com a lei. "[Âncora]: 0 bandido, se fosse esperto, não tinha esse nome... não dá pra chamar de bandido... se eu chamar menor de idade de bandido... não é bandido não, é delinquente, menor infrator..." (VARJÃO, 2015, p. 19).

Os termos utilizados, especialmente pela mídia considerada policialesca, comumente os colocam em situação vexatória, constrangedora, criminalizando-os, indo, portanto, de encontro ao art. 18 do ECA que afirma "É dever de todos velar pela dignidade da criança e do adolescente,

\footnotetext{
${ }^{11}$ Esta temática é composta por discursos que reafirmam a condição de sujeitos de direitos dos adolescentes (BRASIL, 1990, art. 7º; 15; 19²), mesmo quando estão em conflito com a lei. São discursos que se mostram contrários à visão dominante de que os jovens ao cometerem violência, perdem seus direitos.
} 
pondo-os a salvo de qualquer tratamento desumano, violento, aterrorizante, vexatório ou constrangedor" (BRASIL, 1990, Art. 18).

Nesse contexto, o emprego de palavras inadequadas, fora de contexto (como o uso sem critério de expressões presentes na própria legislação) pode reforçar ou criar preconceitos e estereótipos. "No caso dos adolescentes em conflito com a lei, em que os direitos conquistados estão permanentemente ameaçados por uma cultura de criminalização, editores e repórteres precisam estar atentos ao emprego de terminologias que contenham juízos de valor" (ANDI, 2012b, p. 77).

Nesse sentido, vários discursos, identificados no programa Estação Direitos, abordavam a linguagem mais adequada ao tratar sobre os adolescentes autores de atos infracionais.

Hoje a gente não tem mais essa diferença entre quem é criança e quem é menor. Isso é interessante quando a gente vai falar das pessoas, elas não falam "olha, lá em casa tem um menor", elas falam "lá em casa tem uma criança", mas, na rua é o menor, olha "tem um menor que aterroriza a rua", né? Vê, as pessoas ainda trazem isso. Na verdade, o Estatuto diz que todos são crianças e devem ser tratados como crianças. É importante a gente evitar esse termo e falar são crianças e adolescentes e devem ser tratados dessa maneira (PRESIDENTE DA COMISSÃO DA CRIANÇA E DO ADOLESCENTE DA OAB-PA, LUANA TOMAZ, PROGRAMA 4, BLOCO 3).

No trecho reproduzido acima, fica clara a diferença de sentido entre os termos "menor" e "criança" que são considerados sinônimos em muitos contextos. Eles carregam, portanto, significados diferentes ou os mesmos sentidos, dependendo da ou das formações discursivas (FOUCAULT, 1995) nas quais estejam inseridos. Vale ressaltar que um determinado discurso pode "buscar" o sentido das palavras ou expressões que o compõem a partir de uma ou mais formações discursivas.

Outros discursos, nessa mesma linha, referem-se à maneira de tratar o assunto, quando um adolescente descumpre a lei, explicando que o termo correto é ato infracional, não crime. "Quando um adulto rouba ou mata, dizemos que ele cometeu um crime, quando um adolescente infringe a lei, dizemos que cometeu um ato infracional. As palavras diferentes descrevem atitudes iguais" (REPÓRTER, PROGRAMA 1, BLOCO 1).

Inúmeras publicações (VARJÃO, 2015; ALVES, 2018; RIBEIRO, 2020) que denunciam violações de direitos de crianças e adolescentes tratam sobre a linguagem incorreta que é utilizada para referir-se principalmente sobre os adolescentes em conflito com a lei. No entanto, nem todas explicam quais seriam os termos corretos ao abordar o assunto. Ao analisar os cinco programas de rádio, foram identificadas diversas expressões. Abaixo, há uma lista com duas colunas: uma com os termos mais adequados, encontrados nos discursos do programa Estação Direitos, e outra com os termos incorretos, veiculados na mídia, conforme literatura citada acima. 
Quadro 3 - Relação entre termos encontrados no programa e na mídia

\begin{tabular}{|c|c|}
\hline Termos Adequados presentes nos programas analisados & $\begin{array}{c}\text { Termos Incorretos } \\
\text { utilizados pela mídia em } \\
\text { geral }\end{array}$ \\
\hline 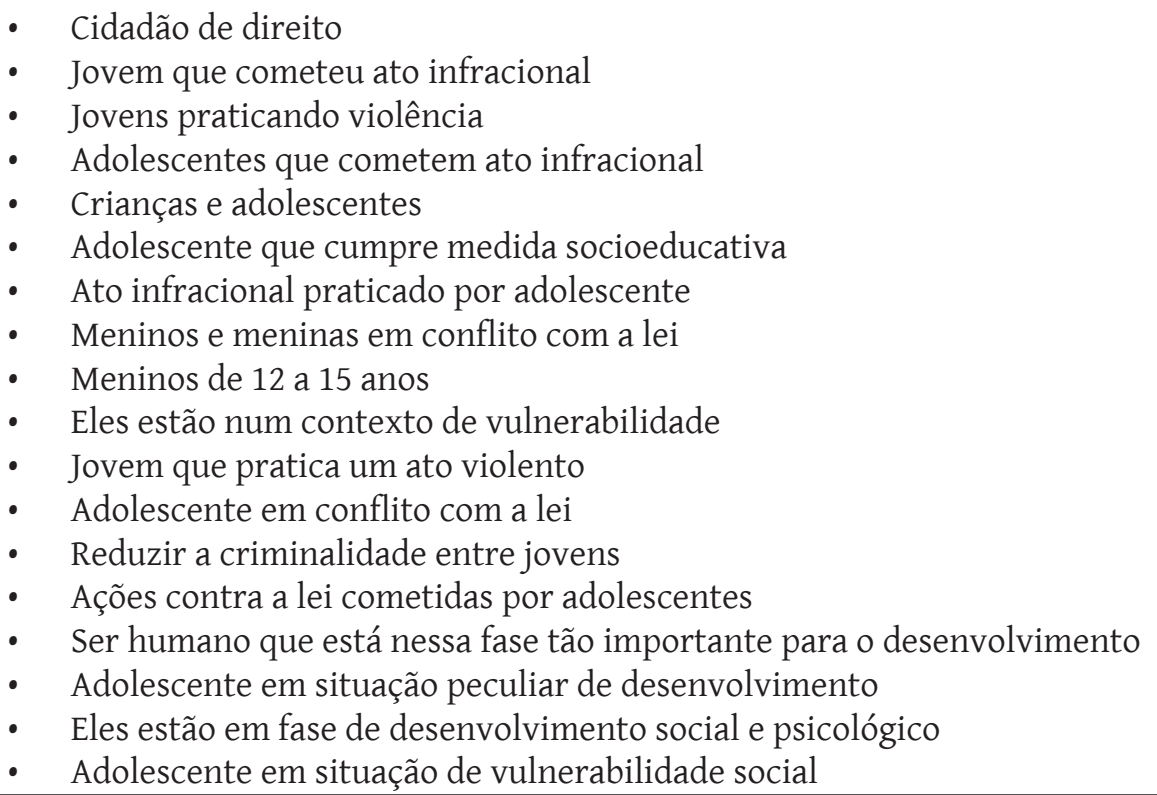 & 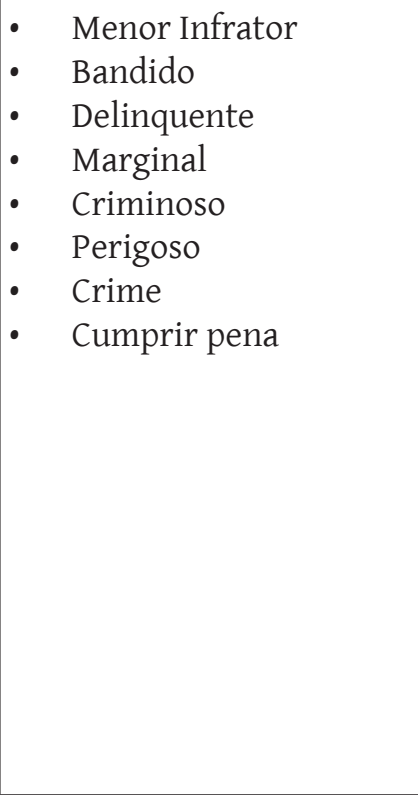 \\
\hline
\end{tabular}

Fonte: coluna à esquerda (dados da pesquisa), coluna à direita (INTERVOZES, 2014; VARJÃO, 2015; ALVES, 2018; RIBEIRO, 2020).

A responsabilização penal (presente em 12 discursos) também foi abordada. Este assunto aparece com vários sentidos. Um no sentido de reafirmar que o adolescente é responsabilizado pelo descumprimento da lei, como neste exemplo: "O adolescente é, sim, responsabilizado quando comete ato infracional e cumpre medidas socioeducativas" (APRESENTADOR, PROGRAMA 1, BLOCO 1) e neste: "Há, sim, toda uma previsão de responsabilização" (ADVOGADO DO CENTRO DE DEFESA DA CRIANÇA E DO ADOLECENTE, BRUNO MEDEIROS, PROGRAMA 3, BLOCO 1).

$O$ discurso da responsabilização penal presente nos programas vai contra um argumento presente no senso comum de que o adolescente não é punido, quando comete um ato infracional. Uma ouvinte abaixo acredita que os adolescentes que cometem atos infracionais se prevalecem da idade para infringir a lei. "Eu acho que deveria reduzir até pra menos, porque se prevalecem disto, entendeste? Então, eles acham que com essa idade, menos de dezoito anos, eles podem fazer o que quiserem que não vai pegar nada pra eles" (OUVINTE, SIMONE SIQUEIRA, PROGRAMA 2, BLOCO 1).

Este argumento é uma consequência da cobertura excessivamente centralizada no ato em si e que pouco aborda as questões referentes à socioeducação, por exemplo, no sentido de esclarecer como ocorre o processo de responsabilização, como citado anteriormente. Nesse sentido, os discursos presentes nos programas de rádio direcionaram-se ao objetivo de desmistificar a pretensa falta de responsabilização penal.

Em outro sentido, a responsabilização imputada ao adolescente é comparada a do adulto.

O adolescente é responsabilizado, mas, é responsabilizado de uma forma diferente da do adulto. Ao adulto é garantido o sistema de segurança pública, a punição, o castigo, mas, para o adolescente, há uma perspectiva diferenciada, 
uma perspectiva de atendimento socioeducativo, então ele é ressocializado, ele é reeducado (PRESIDENTE DA COMISSÃO DOS DIREITOS DA CRIANÇA E DO ADOLESCENTE, DA OAB-PA, LUANA TOMAZ, PROGRAMA 4, BLOCO 2).

O intuito é explicar que há uma visão diferenciada do processo de responsabilização, baseada em um entendimento de que o adolescente, em função de estar em uma condição peculiar do desenvolvimento (presente em quatro discursos), precisa de tratamento diferenciado com vistas à promoção dos direitos (anteriormente violados), portanto, o objetivo não é punir, é reeducar, reintegrar, ressocializar (mais conhecida como a máxima dos "Re"). Em muitos casos, ao contrário do que é veiculado na grande mídia (ANDI, 2013; ALVES, 2018), o sistema de responsabilização é mais severo do que o sistema penal dos adultos.

- Quando apreendido em flagrante por furto, o adolescente é conduzido por policiais militares para delegacia especializada da infância e juventude e pode ficar internado provisoriamente por 45 dias até que haja decisão judicial sobre a autoria. Já um adulto poderia responder em liberdade à acusação; - Adolescentes não têm direito à redução de pena por bom comportamento, prescrição por ação do tempo ou por capacidade demonstrada de readaptação ao convívio social, como prevê o Código Penal em relação aos adultos; • $\mathrm{Na}$ faixa etária de 12 a 17 anos não gozam do benefício de não ter um processo aberto quando as causas são consideradas irrelevantes, como acontece com os adultos (UNICEF, 2011 apud ANDI, 2012a, p. 22).

Por meio dos discursos, é reafirmado que o adolescente é responsabilizado e que o Estatuto possui todo um sistema de responsabilização, desde a apreensão até todo o processo socioeducativo respondido na Justiça. Se a mídia, de uma forma geral, oferecesse maior visibilidade às diferentes fases do processo, a sociedade entenderia o rigor com que a maioria dos casos é tratada pelo sistema. Com isso, o discurso de criminalização (encontrado em seis discursos) e também os discursos presentes no senso comum como o de que o ECA "passa a mão na cabeça" dos adolescentes em conflito com a lei, que os adolescentes não são responsabilizados, que ficam impunes, seriam desmistificados ou, no mínimo, melhor compreendidos.

Outras temáticas foram tratadas nesta formação discursiva, porém, com menos representatividade. São discursos que defendem uma mudança na Lei, de maneira geral, por considerá-la branda (presente em três discursos) e o discurso que se refere ao tempo de Internação dos adolescentes autores de ato infracional, em uma unidade de atendimento socioeducativo (presente em cinco discursos). Os discursos que defendem uma mudança na Lei por considerá-la branda estão no rol de discursos a favor da redução da maioridade penal, seja de forma genérica ou em casos específicos como os de atos infracionais graves.

Eu tenho um pensamento favorável à redução da maioridade penal para 16 anos, no caso de alguns crimes específicos eu sou favorável a essa redução: no caso de estupro, assalto à mão armada, latrocínio, o sequestro e homicídio. Apenas nesses cinco casos eu acredito que pessoas, no caso hoje os adolescentes, eles deveriam ter uma nova legislação (VEREADOR DE BELÉM, RAUL BATISTA, PROGRAMA 3, BLOCO 2).

Ao passo que os discursos sobre o tempo de internação defendem que três anos é um tempo relativamente considerável e representa muito no período da adolescência, contrariando o discurso do senso comum que defende um maior período. "Eu acredito que trinta anos na vida 
de um adulto representam menos em fazeres, em mudanças, do que três anos na vida de um adolescente, exatamente o período em que o desenvolvimento humano ocorre numa velocidade muito grande" (MESTRE EM PSICOLOGIA, RICARDO SANTOS, PROGRAMA 4, BLOCO 2).

Por lei, o tempo máximo de internação é de três anos (BRASIL, 1990, art. 121). Esse artigo do ECA é usado como justificativa para os discursos a favor da redução da maioridade penal que consideram esse período muito curto. 0 entendimento que pode ser inferido a partir dos discursos encontrados é que o período de internação na vida de um adolescente é visto sob uma perspectiva diferenciada do tempo de prisão de um adulto. Os argumentos, portanto, defendem a permanência do período de três anos, por considerar que a adolescência é uma fase da vida humana que tem a duração de seis anos no total, portanto, três corresponderiam à metade desse tempo e também porque é uma fase, na qual as mudanças físicas e psicológicas acontecem de forma muito intensa e célere, representando mudanças significativas em um curto período de tempo.

Isso posto, observou-se que o discurso radiofônico analisado, foi construído a partir de diferentes formações discursivas, com destaque para a política e jurídica, ou seja, os sentidos das palavras que compuseram o discurso dos programas analisados vieram principalmente dessas fontes de significação. Isso não implica que outros discursos não foram acionados, apenas tiveram menos representatividade ao longo dos cinco programas, como o discurso de base cristã, por exemplo, que considera as temáticas do amor, diálogo e afetividade, pouco utilizado no debate público para tratar as questões do universo da maioridade penal.

Outra constatação, com relação a ausência de discursos, refere-se ao discurso midiático. Houve apenas um discurso essencialmente midiático, no qual, foi destacado o sensacionalismo presente ao retratar adolescentes nas páginas policiais: "A cada dia, adolescentes são destaque nas páginas policiais do noticiário" (APRESENTADOR, PROGRAMA 3, BLOCO 1). Apenas este discurso aparece ao longo dos cinco programas. A mídia, de uma forma geral, foi pouco abordada nos programas. Em nenhum programa, foi tratado como é feita a cobertura da grande mídia sobre o assunto, quais as condições de produção das matérias e programas e de que forma a mídia pode produzir e reproduzir subjetividades quando veicula o tema de maneira tendenciosa.

\section{Considerações Finais}

O programa de rádio Estação Direitos, produzido pela ONG Rádio Margarida, seguiu um percurso argumentativo contrário ao do senso comum e ao que é veiculado prioritariamente na grande mídia, deixando claro que é contra a redução da maioridade penal ao priorizar uma abordagem diferenciada, contemplando discursos que possuem pouco espaço na cobertura midiática, como o da carência de políticas públicas, o funcionamento do sistema socioeducativo, a responsabilização preconizada pelo ECA, o contexto de violação, no qual estão inseridos os adolescentes e a importância do Estatuto na garantia dos direitos do segmento infanto-juvenil.

Ao tratar sobre a linguagem, o programa destacou algumas expressões consideradas incorretas, utilizadas não só pela sociedade, mas, pelos agentes públicos, como crime, menor ou infrator, explicitando os motivos pelos quais essas expressões não devem ser usadas, assim como, referiu-se aos temas que permeiam o universo da maioridade penal, destacando os preceitos garantidos pelo ECA e utilizando expressões consideradas aceitáveis no trato sobre adolescentes em conflito com a lei.

Por outro lado, o programa pouco abordou a violação de direitos cometida pela grande mídia, sobretudo na cobertura de assuntos relacionados à maioridade penal, como a espetacularização, 
o sensacionalismo, a utilização de termos incorretos, a incitação à vingança, a criminalização dos adolescentes que cometeram atos infracionais, bem como, não destacou a importância da mídia na produção e reprodução de subjetividades que influenciam diretamente o debate público sobre maioridade penal. Em geral, a mídia foi pouco discutida e analisada nos cinco programas analisados. Apesar de o programa ser um produto midiático, não tratou sobre a própria natureza, a práxis, inerente ao fazer midiático.

Outra consideração sobre a abordagem do programa é que alguns discursos sobre maioridade penal foram exaltados em detrimento de outros. Discursos relevantes para o debate público como o do afeto, da criminalização e do extermínio da juventude, tiveram baixa representatividade no universo total dos programas analisados. Explicitar, por exemplo, o quanto o afeto em diversas dimensões, desde o nascimento até a fase adulta, é um fator essencial para o não envolvimento das crianças e adolescentes com a criminalidade; que criminalizar os jovens é imputar a eles uma responsabilidade que deve ser admitida por todos e que há um número bem maior de mortalidade de adolescentes, principalmente negros e pobres, do que de violência cometida por eles, são questões que se conhecidas pela população, influenciam diretamente o debate sobre a redução da maioridade penal.

No entanto, os programas analisados conseguiram tratar sobre o tema de uma maneira diferenciada do encaminhamento empreendido pela grande mídia, trazendo à luz, outras perspectivas de abordagem, a partir de estratégias discursivas que foram ao encontro do Estatuto da Criança e do Adolescente, ressaltando a condição de sujeitos de direitos, em condição peculiar de desenvolvimento e que necessitam, portanto, de tratamento diferenciado.

Quando comparamos as circunstâncias nas quais o programa foi criado com as em que são produzidos os discursos sobre maioridade penal na grande mídia, observa-se que são contextos diferenciados, com finalidades muitas vezes divergentes (socioeducação x aumento da audiência para fins comerciais) e que, portanto, geram sentidos diferentes. No entanto, as iniciativas de minorias, como a proposta pelo programa de rádio analisado, podem fazer frente ao discurso dominante e criar uma alternativa de comunicação que vise a intervir na realidade no sentido de trazer à luz discursos silenciados, perspectivas outras que possam influenciar e contribuir para mudança de uma ordem social instituída e do próprio discurso midiático dominante.

\section{Referências}

ALVES, Daniela do Canto. Mídia e redução da maioridade penal: as representações sociais sobre o adolescente em conflito com a lei no telejornalismo da Rede Record Dissertação (Mestrado) Universidade Estadual Paulista. Faculdade de Arquitetura, Artes e Comunicação, Bauru, 2018.

AMARO, Jorge Wohney Ferreira. o debate sobre a maioridade penal. Revista de Psiquiatria Clínica, v. 31, n. 3, p. 142-144, 2004.

ANCED. II Relatório Alternativo sobre a Convenção Internacional sobre os Direitos da Criança (CDC). Resumo Executivo. Período relatado: 2004 - 2012, apresentado ao Comitê de Direitos da Criança da ONU. 3 Fev. 2015. Disponível em: <http://www.anced.org.br/wp-content/uploads/2015/02/ Resumo-Executivo-CDC_Anced-2014.pdf>. Acesso em 12 jan. 2018.

ANDI - Agência de Notícias dos Direitos da Infância. Relatório Infância na Mídia. (ISSN 1519-1702). Ano 10. Número 14. Jul. 2005. 
ANDI - COMUNICAÇÃO E DIREITOS. Infância e comunicação: referências para o marco legal e as políticas públicas brasileiras. Brasília: ANDI, 2011.

ANDI - Direitos em Pauta: Imprensa, agenda social e adolescentes em conflito com a lei - uma análise da cobertura de 54 jornais brasileiros entre 2006 e 2010. Brasília: ANDI, 2012a.

ANDI - Adolescentes em conflito com a lei. Guia de referência para a cobertura jornalística. Brasília: ANDI, 2012b.

ANDI - A mídia brasileira e as regras de responsabilização dos adolescentes em conflito com a lei. Análise Crítica. Brasília: ANDI, 2013.

ANDRADE, Marcia Siqueira de. Liberdade dos corpos e processos de subjetivação em adolescentes. In: NETO, João Clemente de Souza Neto; NASCIMENTO, Maria Letícia B. P. Infância: violência, instituições e políticas públicas. São Paulo: Expressão e arte, 2006. p. 203 - 227.

ARAÚJO, Inesita. A Reconversão do Olhar: prática discursiva e produção dos sentidos na intervenção social. São Leopoldo, RS: Unisinos, 2000.

BALAS Perdidas: um olhar sobre o comportamento da imprensa brasileira quando a criança e o adolescente estão na pauta da violência. Brasília: Agência de Notícias dos Direitos da Infância/ANDI, Amencar, DCA-MJ, 2000.

BRANDÃO, Helena Hathsue Nagamine. Introdução à análise do discurso. $3^{\mathrm{a}}$ ed. rev. - Campinas, SP: Editora da Unicamp, 2012.

BRASIL. Estatuto da Criança e do Adolescente: Lei federal nº 8069, de 13 de julho de 1990.

BRASIL. [Constituição (1988)]. Constituição da República Federativa do Brasil: promulgada em 5 de outubro de 1988.

BRASIL. Ministério da Mulher, da Família e dos Direitos Humanos (MMFDH). Levantamento Anual Sinase 2017. Brasília: Ministério da Mulher, da Família e dos Direitos Humanos, 2019.

BRASÍLIA. Câmara dos Deputados. Proposta de Emenda à Constituição ${ }^{\circ}$ 115, de 2015. Altera a redação do art. 228 da Constituição Federal que dispõe que são penalmente inimputáveis os menores de dezoito anos, sujeitos às normas da legislação especial. Disponível em: <https://www25.senado.leg. br/web/atividade/materias/-/materia/122817>. Acesso em: 20 jul 2020.

CAL, Danila Gentil Rodriguez; SANTOS, Breno Augusto Mendes dos. Adolescentes infratores na cena pública: como os media alimentam o debate sobre a redução da maioridade penal. ContemporâneaRevista de Comunicação e Cultura, v. 13, n. 1, p. 140-158, 2015.

CARLSSON, Ulla; FEILITZEN, Cecília Von. A criança e a mídia: imagem, educação, participação. - São Paulo: Cortez; Brasília, DF: UNESCO, 2002.

CERIONI, Clara. Datafolha: 84\% dos brasileiros querem redução da maioridade penal. EXAME. Publicada em: 14 jan 2019. Disponível em: <https://exame.com/brasil/maioria-quer-reducao-da-maioridadepenal-de-18-para-16-anos-diz-datafolha/>. Acesso em: 20 mai 2020.

CHARAUDEAU, P. e MAINGUENEAU, D. Dictionnaire d'analyse du discours. Paris, Éditions du Seuil. 2002.

COSTA, Luciana Miranda. As Mudanças Climáticas na pauta da mídia impressa Brasileira: informação e desinformação na construção de políticas públicas para a Amazônia. Relatório final de pesquisa apresentado ao CNPq. 2013. 
FIORIN, J. Linguagem e Ideologia. 4 ed. Editora: Ática, São Paulo, 1995.

FOUCAULT, Michel. A arqueologia do saber. Rio de Janeiro: Forense Universitária, $4^{a}$ ed., 1995.

GREGOLIN, Maria. Análise do discurso e mídia: a (re) produção de identidades. Comunicação mídia e consumo, v. 4, n. 11, p. 11-25, 2008.

IPEA. (2019). Atlas da Violência. Taxa de Homicídios Faixa Etária de 15 - 29 anos. Disponível em: https://www.ipea.gov.br/atlasviolencia/dados-series/25. Acesso em: 29 mai 2020.

INTERVOZES. Guia Mídia e Direitos Humanos / Iara Moura (autora) e Paulo Victor Melo (coordenador) - 1. Ed. - São Paulo: Intervozes, 2014.

MAINGUENEAU, D. Nouvelles tendences em analyse du discours. Paris: Hachette, 1987.

MATTOS, M. A., JANOTTI JUNIOR, J., and JACKS, N. (Orgs). Mediação \& midiatização [online]. Salvador: EDUFBA, 2012, 328p.

NJAINE, Kathie; VIVARTA, Veet. Violência na Mídia: excessos e avanços. Direitos negados: a violência contra a criança e o adolescente no Brasil. ANDI, 2005.

NERY, Lena. Imagem violada: estereótipos e desrespeito aos direitos do adolescente em conflito com a lei nos jornais Diário do Pará e O liberal. 2008. 78f. Monografia (especialização Imagem e sociedade) Instituto de Letras e Comunicação, Universidade Federal do Pará, Belém, 2008.

ODON, Tiago Ivo. Maioridade Penal: Breves Considerações. Boletim do Legislativo nº 13, 2013. Disponível em: <http://www12.senado.gov.br/publicacoes/estudos-legislativos/tipos-de-estudos/boletins-

legislativos/boletim-no-13-de-2013-maioridade-penal-breves-consideracoes>. Acesso em 3 jul. 2015

ORLANDI, Eni Puccinelli. Análise de discurso: princípios e procedimentos. Campinas: Pontes, 2001.

PAIVA, Raquel; BARBALHO, Alexandre (Organizadores). Comunicação e cultura das minorias. São Paulo: Paulus, 2005.

PASTORELLI, Ivanéa Maria. Manual de impressa e de mídia. São Paulo: 2001.

POSSENTI, Sírio. Observações sobre interdiscurso. Revista Letras, Curitiba, n. 61, p. 253-269, 2003.

RIBEIRO, Fábio. O Apelo à ordem nos telejornais policiais. Plural-Revista De Ciências Sociais, v. 27, n. 1, p. 231-255, 2020.

RODRIGUES, Amanda Caroline. Mídia e construção de sentido: o olhar de adolescentes em internação provisória sobre a redução da maioridade penal. Mestrado em Comunicação (Dissertação). Programa de Pós-Graduação em Comunicação. Brasília: Universidade Católica de Brasília, 2018.

ROTHBERG, Danilo. Enquadramentos midiáticos e sua influência sobre a consolidação de direitos de crianças e adolescentes. Opinião Pública, v. 20, n. 3, p. 407-424, 2014.

SAFATLE, Wladimir. Nós, o lixo marxista. Folha de São Paulo. Colunas e blogs. Disponível em: <https://www1.folha.uol.com.br/colunas/vladimirsafatle/2019/01/nos-o-lixo-marxista.shtml>. Acesso em: 2 Jan 2019.

SOARES, Jussara. Bolsonaro diz que ECA deve ser "rasgado e jogado na latrina". o Globo. Publicado em: 23 ago 2018. Disponível em: <https://oglobo.globo.com/brasil/bolsonaro-diz-que-eca-deve-serrasgado-jogado-na-latrina-23006248>. Acesso em 30 mai 2020. 
UNICEF. O direito de ser adolescente: oportunidade para reduzir vulnerabilidades e superar desigualdades. Brasília: UNICEF, 2011. Disponível em: <http://www.unicef.org/brazil/pt/br_sabrep11. pdf>. Acesso em: 12 jan. 2016.

VARJÃO, Suzana. Violações de direitos na mídia brasileira: ferramenta prática para identificar violações de direitos no campo da comunicação de massa / Suzana Varjão. Brasília, DF: ANDI, 2015. 